\title{
Oculocutaneous anthrax: detection and treatment
}

This article was published in the following Dove Press journal:

Clinical Ophthalmology

30 June 2010

Number of times this article has been viewed

\author{
Sarada David' \\ Jayanthi Peter' \\ Renu Raju ${ }^{2}$ \\ P Padmaja ${ }^{2}$ \\ Promila Mohanraj ${ }^{2}$ \\ 'Department of Ophthalmology, \\ Schell Eye Hospital, Christian \\ Medical College Hospital, Vellore, \\ India; ${ }^{2}$ Department of Microbiology, \\ Christian Medical College Hospital, \\ Vellore, India
}

Correspondence: Jayanthi Peter Schell Eye Hospital, Christian Medical College and Hospital, Arni Road, Vellore 632001 , India

$\mathrm{Tel}+9|4| 6228$ I20I

Fax +9| 416228 I2I5

Email peterjohnvictor@yahoo.com.au
Abstract: Anthrax, a zoonotic disease that primarily affects herbivores, has received recent attention as a potential agent of bioterrorism. We report a patient who presented with a 4-day history of pain, watering and difficulty in opening the left upper and lower eyelids, and fever. Clinical examination revealed brawny nonpitting edema with serosanguinous discharge. The history of the death of his sheep 1 week prior to the illness provided the clue to the diagnosis. Although standard cultures of the blood and the serous fluid from the lesion were negative, probably as a result of prior treatment, the diagnosis of cutaneous anthrax was made by a polymerase chain reaction (PCR) test of the serous fluid. Serial photographs demonstrating resolution of the lesion with appropriate antibiotic therapy are presented.

Keywords: anthrax, polymerase chain reaction, treatment

\section{Introduction}

Anthrax, a zoonotic disease caused by Bacillus anthracis (B. anthracis), primarily affects herbivores including sheep, cattle, horses, and other domestic animals. ${ }^{1}$ Humans may be affected as a result of exposure to an infected animal or animal products. This organism has received recent attention as a potential agent of bioterrorism. ${ }^{1}$ Three forms are described: cutaneous, inhalational, and gastrointestinal. ${ }^{1}$ We describe a patient with oculocutaneous anthrax.

\section{Case description}

A 39-year-old male presented to our outpatient clinic with a 4-day history of fever and swelling of the left upper and lower eyelids associated with pain, watering, and difficulty in opening the eyelids. He reported that his sheep had died suddenly 1 week prior to his illness. There was no past history of any medical illness. The patient reported that he was prescribed tablets and injections by a general practitioner, but was unable to provide details of this treatment to us.

On examination, there was brawny nonpitting edema of the upper and lower eyelids of the left eye and left side of the face (Figure 1). There was an ulceration and black discoloration along the left lower lid margin with serosanguinous discharge. His visual acuity was 20/20 in both the eyes. The anterior and posterior segments of both the eyes were within normal limits. A diagnosis of oculocutaneous anthrax was considered based on the history and clinical findings. Serous fluid from the eyelid and blood were collected and sent for conventional cultural methods and polymerase chain reaction (PCR) test. The Gram stain of the serous fluid revealed no leucocytes or 


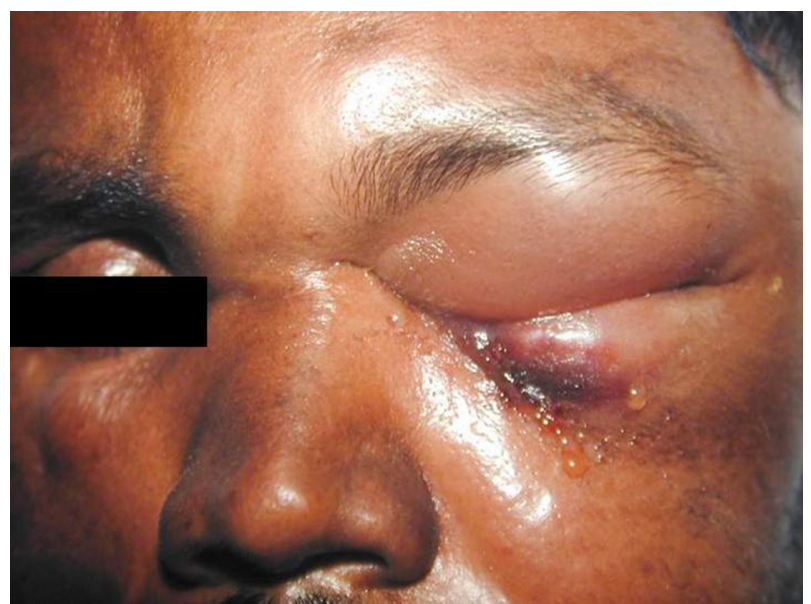

Figure I Brawny nonpitting edema of the upper and lower eyelids of the left eye with serosanguinous discharge

bacteria. Cultures of the serous fluid and blood were negative for B. anthracis.

\section{PCR method for the detection of $B$. anthracis}

The patient's DNA was extracted using the QIA amp DNA blood mini kit (QIAGEN, Hilden, Germany) according to the manufacturer's instruction. A 596-bp fragment of the protective antigen (PA) gene, PA (F)-TCC TAA CAC TAA CGA AGT CG and PA (R)-GAG GTA GAA GGA TAT ACG GT and a 846-bp fragment of the capsule (CAP) gene, CAP (F)-CTG AGC CAT TAA TCG ATA TG and CAP (R) ${ }^{2,3}$ of $B$. anthracis were used as the target for anthrax PCR. The DNA was amplified in a total volume of $50 \mu \mathrm{L}$ with the above mentioned primers, $200 \mu \mathrm{m}$ (each) deoxynucleotide triphosphates, 1X PCR buffer, $1.5 \mathrm{mM} \mathrm{MgCL}_{2}$ and 2.5 units of Taq polymerase (Amplitaq Gold-Applied Biosystems, California, USA) and followed by the addition of $5 \mu \mathrm{L}$ of the template DNA. Thermal cycling was performed at $94^{\circ} \mathrm{C}$ for 5 minutes (initial denaturation) followed by 35 cycles at $94^{\circ} \mathrm{C}$ for 1 minute, $52^{\circ} \mathrm{C}$ for 1 minute (annealing), $72^{\circ} \mathrm{C}$ for 2 minutes (extension) and the final extension at $72^{\circ} \mathrm{C}$ for 5 minutes; cooled to $4{ }^{\circ} \mathrm{C} .{ }^{4}$ Thermal cycling was done in the Gene AMP PCR system 9200 (Applied Biosystems, California, USA).

A $15 \mu \mathrm{L}$ portion of the PCR product and $5 \mu \mathrm{L}$ of $10 \%$ tracking dye $(0.02 \%$ xylene cyanol, $0.02 \%$ bromophenol blue and $50 \%$ glycerol) was added to the PCR tube. Fifteen microliters of this mix were loaded into the wells in the agarose (Amersham Pharmacia, New Jersey, USA). The PCR products were analyzed by submarine gel electrophoresis through a $1 \%$ agarose gel in $1 \mathrm{X}$ TAE buffer. The gel was run at 120 volts for 60 minutes, stained with $0.5 \mu \mathrm{g} / \mathrm{mL}$ of ethidium bromide (Amersham Pharmacia, New Jersey, USA), visualized and recorded under $\mathrm{UV}^{4}$ in the Gel Doc 2000 System (Bio-Rad, California, USA). The Gene Ruler ${ }^{\mathrm{TM}}$ 100-bp (3000-100bp) DNA Ladder Plus (MBI Fermentas, USA) was used as the molecular standard. The PCR from the fluid and the blood were positive for the gene encoding the protective antigen (PA gene) and the capsule (CAP gene) of B. anthracis (Figure 2).

\section{Clinical course of the patient}

The patient was started on injection crystalline penicillin, 2 million international units $(1250 \mathrm{mg})$ every 2 hours intravenously. No topical therapy was prescribed, however, the patient was given anti-inflammatory agents (ibuprofen). The patient responded well to antibiotic therapy with reduction of fever and lid edema. A black eschar developed within a few days of treatment (Figure 3). On completion of a 10-day course of intravenous antibiotics, he was discharged on oral penicillin G $500 \mathrm{mg}$ every 6 hours. The total duration of antibiotic therapy including intravenous antibiotics was 6 weeks. Although the eschar reduced in size over time, it was firmly adhered to the underlying tissue. When the eschar was removed after 1 month of the onset of illness, an ulcerated undersurface was observed (Figure 4). The ulceration healed over the next 2 weeks with scarring and ectropion of the left lower lid (Figure 5). The low grade lid edema and mechanical ptosis of the left upper eyelid resolved over the next few weeks.

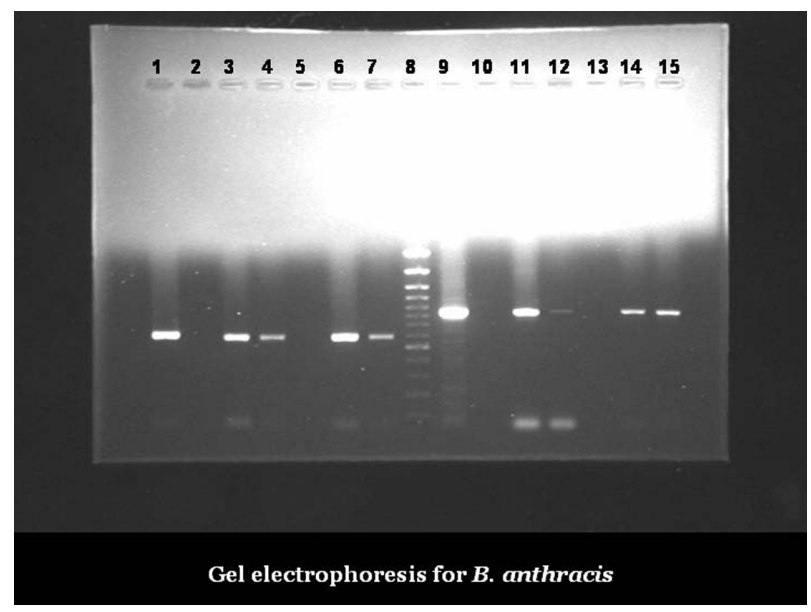

Figure 2 Gel electrophoresis for B. anthracis.

Notes: Lane I and 9- PA and CAP (positive control); Lane 2 and 10- PA and CAP (negative control); Lane 3 and II- undiluted DNA for PA and CAP (serous fluid); Lane 4 and I2- I/I 0 diluted DNA for PA and CAP (serous fluid); Lane 5 and 13- water blank; Lane 6 and I4- undiluted DNA for PA and CAP (blood); Lane 7 and I5- I/I 0 diluted DNA for PA and CAP; Lane 8- marker (I00-bp ladder). 


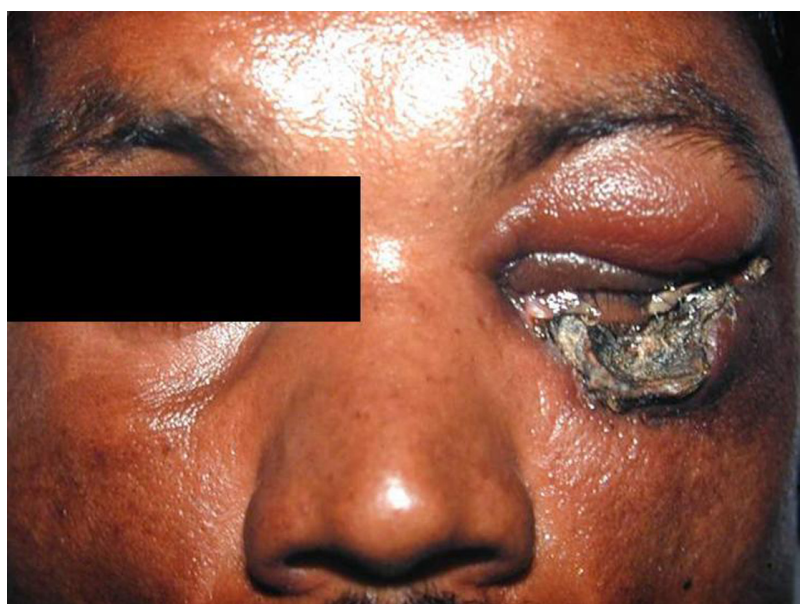

Figure 3 Black eschar involving the left lower lid with residual edema of the left upper lid.

\section{Comments}

B. anthracis is commonly found in agricultural environments. It is a Gram-positive, aerobic, endospore-forming bacilli that, in the vegetative form, has a poor survival rate outside an animal or human host. ${ }^{5}$ It is capable of producing fatal infection in livestock and in humans. ${ }^{1}$ Anthrax is considered to be one of most dangerous biological weapons. ${ }^{6}$ Humans are infected when spores are introduced into the body by contact with infected animals or animal products. ${ }^{1}$ Cutaneous anthrax has been reported to occur as preseptal cellulitis in the eyelids. ${ }^{7,8}$ Cutaneous anthrax, if untreated, leads to lifethreatening septicemia. ${ }^{1}$

This report highlights that a high index of clinical suspicion and prompt institution of appropriate therapy are essential for a successful outcome. Since lesions can become sterile within 24 hours of antimicrobial therapy, confirmation

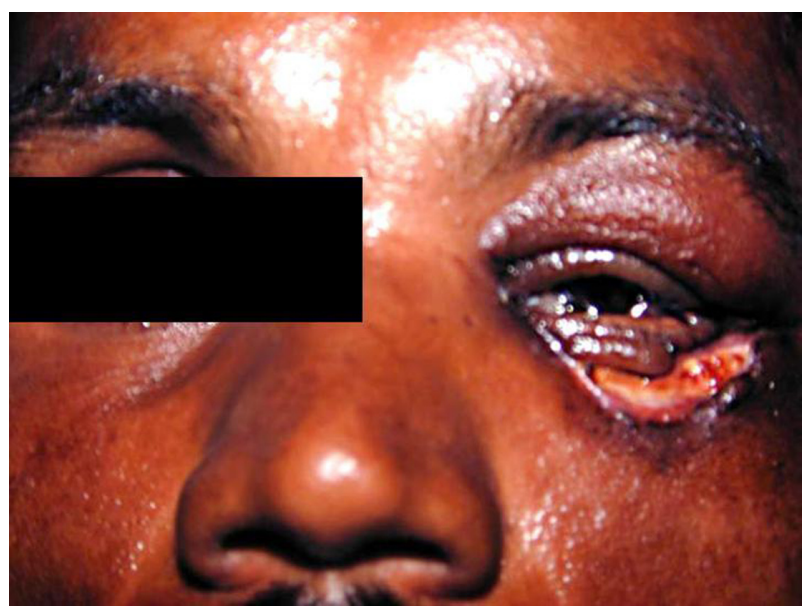

Figure 4 Ulcerated undersurface of the left lower lid on removal of the eschar.

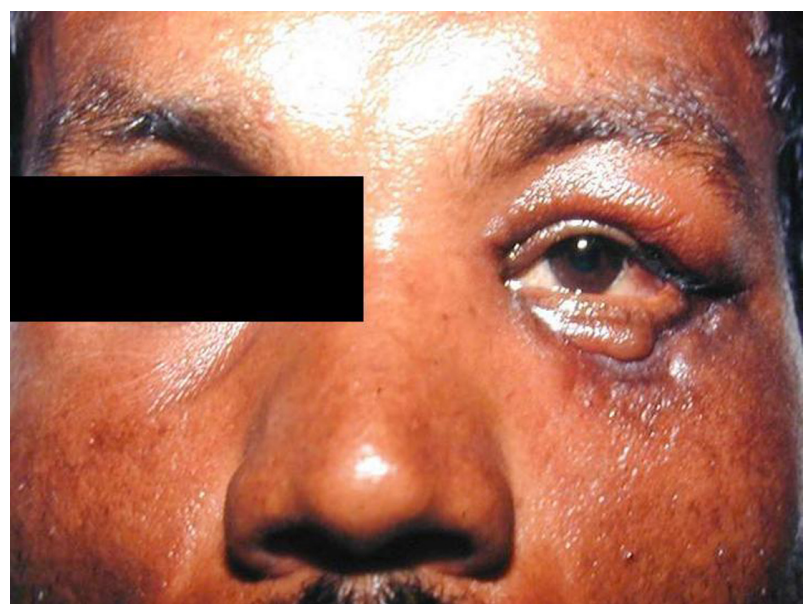

Figure 5 Scarring and ectropion of the left lower lid.

of diagnosis can be made using $\mathrm{PCR},{ }^{2-4,9}$ as was done in our patient, when the conventional cultural methods fail to identify the etiology or when patients have already received antimicrobial therapy.

\section{Acknowledgments}

SD-study conception, acquisition of data and photographs, literature review, critical appraisal of the write up, and approval of the final version of the manuscript; JP-literature review, write up of the article, and approval of the final version of the manuscript; RR-literature review, acquisition of data and photographs, critical appraisal of the article, and approval of the final version of the manuscript; PP-microbiological aspects and approval of the final version of the manuscript; PM-microbiological aspects, critical appraisal of the write up, and approval of the final version of the manuscript.

\section{Disclosures}

The authors report no conflicts of interest in this work.

\section{References}

1. Spencer RC. Bacillus anthracis. J Clin Pathol. 2003;56:182-187.

2. Beyer W, Glockner P, Otto J, Bohm R. A nested PCR and DNA amplification fingerprinting method for detection and identification of B. anthracis in soil samples from former tanneries. Salisbury Med Bull. 1996;87 Suppl:47-49.

3. Hutson RA, Duggleby CJ, Lowe JR, Manchee RJ, Turnbull PC. The development and assessment of DNA and oligonucleotide probes for the specific detection of B. anthracis. J Appl Bacteriol. 1993;75: 463-472.

4. Turnbull PCB. Guidelines for the surveillance and control of anthrax in humans and animals. 3rd ed. World Health Organization. Geneva, (WHO/ EMC/ ZDI/ 98.6) 1998:60-62.

5. Petsko GA. Winter, plague and pestilence. Genome Biol. 2001; 2:COMMENT1013. Epub 2001 Oct 23. 
6. Inglesby TV, O'Toole T, Henderson DA, et al. Anthrax as a biological weapon: Updated recommendations for management. JAMA. 2002;287:2236-2252.

7. Celebi S, Aykan U, Alagoz G, Esmerligil S. Palpebral anthrax. Eur J Ophthalmol. 2001;11:171-174.

8. Soysal HG, Kiratli H, Recep OF. Anthrax as a cause of preseptal cellulitis and cicatricial ectropion. Acta Ophthalmol Scand. 2001;79:208-209.
9. Hadjinicolaou AV, Demetriou VL, Hezka J, Beyer W, Hadfield JL, Kostrikis LG. Use of molecular beacons and multiallelic real-time PCR for detection of and discrimination between virulent Bacillus anthracis and other Bacillus isolates. J Microbiol Methods. 2009;78:45-53.

\section{Publish your work in this journal}

Clinical Ophthalmology is an international, peer-reviewed journal covering all subspecialties within ophthalmology. Key topics include: Optometry; Visual science; Pharmacology and drug therapy in eye diseases; Basic Sciences; Primary and Secondary eye care; Patient Safety and Quality of Care Improvements. This journal is indexed on

\section{Dovepress}

PubMed Central and CAS, and is the official journal of The Society of Clinical Ophthalmology (SCO). The manuscript management system is completely online and includes a very quick and fair peer-review system, which is all easy to use. Visit http://www.dovepress.com/ testimonials.php to read real quotes from published authors. 